Key Words:

Tank $50 \mathrm{H}$

Cesium

Tetraphenylborate

\title{
Tank 50H Tetraphenylborate Destruction Results
}

\author{
T. B. Peters \\ S. D. Fink
}

June 12, 2003

Westinghouse Savannah River Company

Savannah River Site

Aiken, SC 29808

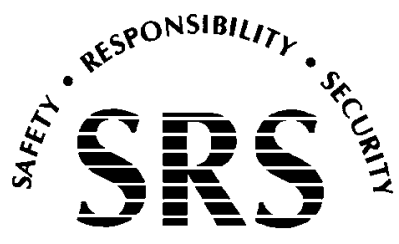

SAVANNAH RIVER SITE

Prepared for the U.S. Department of Energy Under Contract Number DE-AC09-96SR18500 
This document was prepared in conjunction with work accomplished under Contract No. DE-AC09-96SR18500 with the U. S. Department of Energy.

\section{DISCLAIMER}

This report was prepared as an account of work sponsored by an agency of the United States Government. Neither the United States Government nor any agency thereof, nor any of their employees, makes any warranty, express or implied, or assumes any legal liability or responsibility for the accuracy, completeness, or usefulness of any information, apparatus, product or process disclosed, or represents that its use would not infringe privately owned rights. Reference herein to any specific commercial product, process or service by trade name, trademark, manufacturer, or otherwise does not necessarily constitute or imply its endorsement, recommendation, or favoring by the United States Government or any agency thereof. The views and opinions of authors expressed herein do not necessarily state or reflect those of the United States Government or any agency thereof.

This report has been reproduced directly from the best available copy.

Available for sale to the public, in paper, from: U.S. Department of Commerce, National Technical Information Service, 5285 Port Royal Road, Springfield, VA 22161, phone: (800) 553-6847, fax: (703) 605-6900

email: orders@ntis.fedworld.gov

online ordering: http://www.ntis.gov/help/index.asp

Available electronically at http://www.osti.gov/bridge

Available for a processing fee to U.S. Department of Energy and its contractors, in paper, from: U.S. Department of Energy, Office of Scientific and Technical Information, P.O. Box 62, Oak Ridge, TN 37831-0062,

phone: (865)576-8401,

fax: (865)576-5728

email: $\underline{\text { reports@ adonis.osti.gov }}$ 
This page intentionally left blank 
WSRC-TR-2003-00234

\section{List of Abbreviations}

3PB

2PB

$1 \mathrm{~PB}$

ADS

ARP

Cs

DF

ECC

HLW

HPLC

SRTC

SWPF

TPB

WPTS

wrt triphenyl boron

diphenylborinic acid

phenylboronic acid

Analytical Development Section

Actinide Removal Process

Cesium

Decontamination Factor

Enhanced Catalyst Composition

High Level Waste

high-pressure liquid chromatography

Savannah River Technology Center

Salt Waste Processing Facility

Tetraphenylborate

Waste Processing Technology Section

with respect to 
WSRC-TR-2003-00234

\subsection{Executive Summary}

We conducted several scoping tests with both Tank 50H surrogate materials (KTPB and phenol) as well as with actual Tank $50 \mathrm{H}$ solids. These tests examined whether we could destroy the tetraphenylborate in the surrogates or actual Tank $50 \mathrm{H}$ material either by use of Fenton's Reagent or by hydrolysis (in Tank $50 \mathrm{H}$ conditions at a maximum temperature of $50^{\circ} \mathrm{C}$ ) under a range of conditions. The results of these tests showed that destruction of the solids occurred only under a minority of conditions.

- Using Fenton's Reagent and KTPB as the Tank 50H surrogate, no reaction occurred at $\mathrm{pH}$ ranges greater than 9.

- Using Fenton's Reagent and phenol as the Tank 50H surrogate, no reaction occurred at a $\mathrm{pH}$ of 14.

- Using Fenton's Reagent and actual Tank 50H slurry, a reaction occurred at a $\mathrm{pH}$ of 9.5 in the presence of ECC additives.

- Using Fenton's Reagent and actual Tank 50H slurry, after a thirty three day period, all attempts at hydrolysis (at $\mathrm{pH} 14$ ) were too slow to be viable. This happened even in the case of higher temperature $\left(50^{\circ} \mathrm{C}\right)$ and added $(100 \mathrm{ppm})$ copper.

\subsection{Introduction}

Tank $50 \mathrm{H}$ is scheduled to return to HLW Tank Farm service with capabilities of transferring and receiving salt supernate solutions to and from the Tank Farms and staging feed for the Saltstone Facility. Before returning Tank 50H to Tank Farm service as a non-organic tank, less than $5 \mathrm{~kg}$ of TPB must remain in Tank $50 \mathrm{H}$. Recently, camera inspections in Tank $50 \mathrm{H}$ revealed two large mounds of solid material, one in the vicinity of the B5 Riser Transfer Pump and the other on the opposite side of the tank. ${ }^{1}$ Personnel sampled and analyzed this material to determine its composition. ${ }^{2}$ The sample analysis indicated presence of a significant quantity of organics in the solid material. This quantity of organic material exceeds the $5 \mathrm{~kg}$ limit for declaring only trace amounts of organic material remain in Tank $50 \mathrm{H}$. Additionally, these large volumes of solids, calculated ${ }^{3}$ as approximately $61 \mathrm{~K}$ gallons, present other obstacles upon returning Tank $50 \mathrm{H}$ to HLW service. The concerns include the potential for retention of flammable gases, nuclear criticality safety implications, and possible combustible solids formation. A recent document describes the initial results of that work. ${ }^{4}$ 
Additional scope was requested by the customer at a later date. The Technical Task Request HLE-TAR-2003-081 asks SRTC to perform scoping studies on the feasibility of destroying the organics in Tank $50 \mathrm{H}$ itself. While most of the TPB can be removed by suspending and transfer to Saltstone, the heel of material may prove problematic. Destruction in place may be required.

\subsection{Experimental Detail}

The Task Request specified that we should conduct scoping tests on Tank $50 \mathrm{H}$ organics (TPB). At that time, Fenton's Reagent appeared the most promising candidate on the horizon. As work progressed, the customer requested that we also study phenylborate hydrolysis.

\subsection{Fenton's Reagent Testing}

The Fenton Reagent is a "practical, inexpensive, green chemical process for degrading environmental pollutants". 5 Fenton's Reagent is used to treat a variety of industrial wastes containing a range of toxic organic compounds (e.g., phenols, formaldehyde, and complex wastes derived from dyestuffs, pesticides, wood preservatives, plastics additives, and rubber chemicals). The process has been applied to wastewaters, sludges, and contaminated soils. ${ }^{6}$ Fenton's Reagent has been used to solve a number of environmental problems involving the destruction of organic contaminants in soil and groundwater including a collaborative effort between Geo-Cleanse International, Inc. and WSRC in 1997. ${ }^{7}$ Fenton's Regent (a combination of iron and hydrogen peroxide) produces hydroxyl radicals known to oxidatively degrade organic materials, ideally yielding carbon dioxide. In our tests with Fenton's Reagent, we used $250 \mathrm{~mL}$ reaction vessels (Figure 1), set up as shown in Figure 2. Each test occurred at room

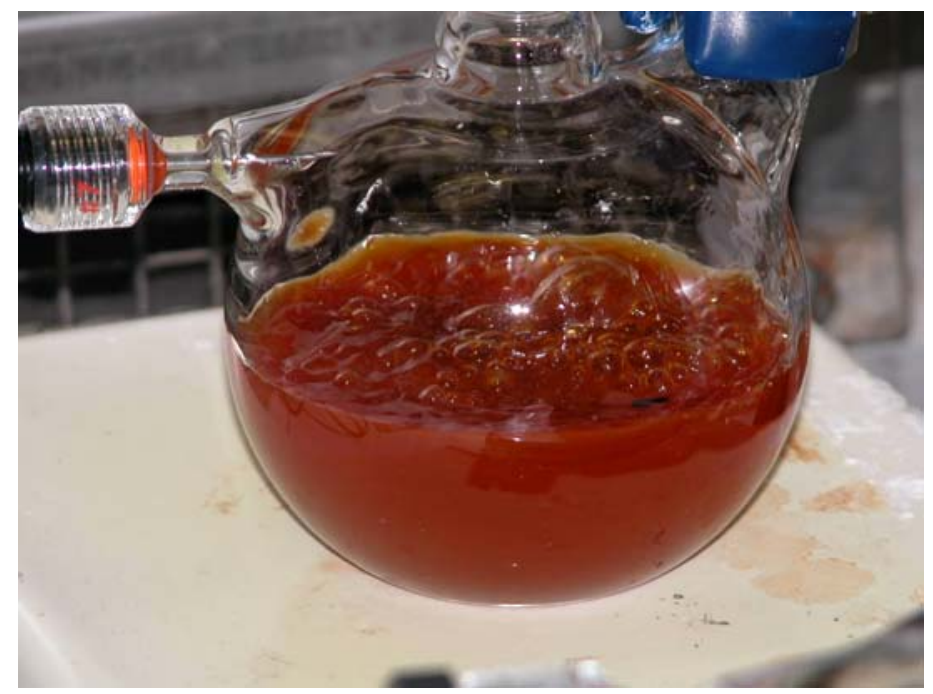

Figure 1. Glass Reaction Vessel 


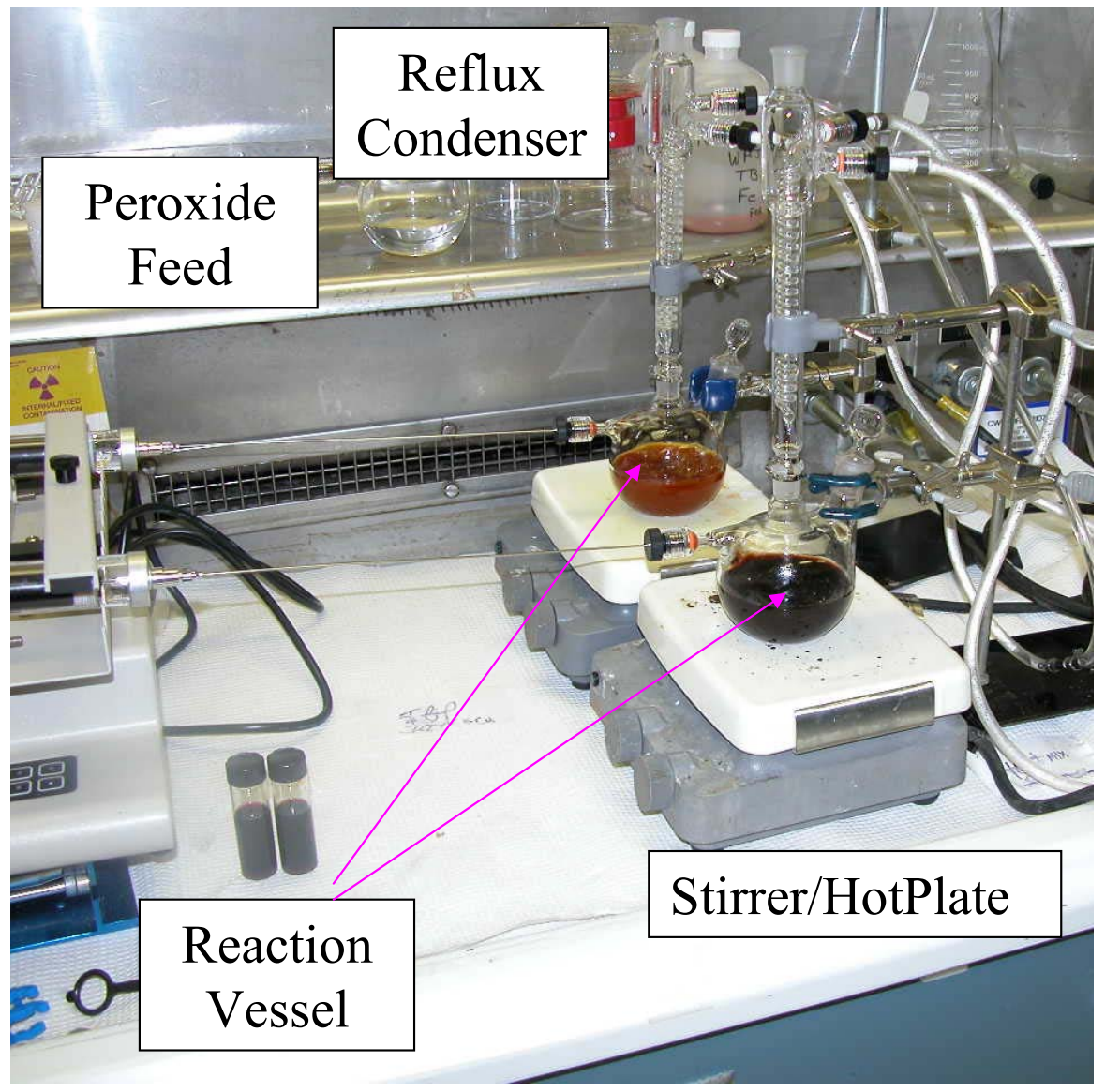

Figure 2. Experimental Setup for Fenton's Reagent Reactions

temperature with the $\mathrm{H}_{2} \mathrm{O}_{2}$ added over a four hour time period. At the end of the four hours, personnel sealed the flask and sent it to the Analytical Development Section (ADS). The analyst extracted the entire organic contents of the flask with acetonitrile and analyzed via high-pressure liquid chromatography (HPLC) for phenylborates and phenol. As a surrogate for actual Tank $50 \mathrm{H}$ slurry, we used either freshly precipitated KTPB or phenol.

\subsection{Phenylborate Hydrolysis}

Tetraphenylborate is known to undergo hydrolysis at lower $\mathrm{pH}$ values, and this can be accelerated by the addition of copper compounds. For example, the phenylborate contents in Tank $49 \mathrm{H}$ were remediated using copper aided hydrolysis in $2000 .^{8}$ For this work, researchers studied the behavior of actual Tank $50 \mathrm{H}$ slurry. We performed four parallel tests: 
WSRC-TR-2003-00234

- Room temperature, no added copper, $\mathrm{pH} 14$

- Room temperature, 100 ppm added copper, $\mathrm{pH} 14$

- $50^{\circ} \mathrm{C}$ temperature, no added copper, $\mathrm{pH} 14$

- $50{ }^{\circ} \mathrm{C}$ temperature, $100 \mathrm{ppm}$ added copper, $\mathrm{pH} 14$

In each test, personnel continuously agitated five $30 \mathrm{~mL}$ polypropylene bottles of Tank $50 \mathrm{H}$ slurry for the duration of the test. We removed a bottle of each slurry 1, 2, 3, 14, and 33 days after the start of each test and sent to ADS for analysis. Personnel extracted the organic contents of each bottle with acetonitrile and analyzed via HPLC for phenylborates and phenol.

\subsection{Results of Investigations}

\subsection{Results of Fenton's Reagent Tests}

\subsubsection{Test with KTPB}

The first tests used KTPB as a surrogate for Tank $50 \mathrm{H}$ solids. We freshly precipitated the KTPB in the reactor by the reaction of equimolar amounts $\mathrm{KNO}_{3}$ and $\mathrm{NaTPB} .100 \mathrm{~mL}$ of salt solution was used in each reaction, and each reaction was done at room temperature. The target amount of KTPB equaled $500 \mathrm{mg}$. In addition to the KTPB, each reaction used one of two supernate salt solutions; "Low OH" or "High OH" (see Table 1).

Table 1. Composition of the Low and High OH Salt Solutions

\begin{tabular}{|l|c|c|}
\hline & Low OH & High OH \\
\hline Component & Molarity & Molarity \\
\hline Total Na & 5.60 & 5.60 \\
\hline $\mathrm{NaOH}$ & 1.17 & 3.05 \\
\hline $\mathrm{NaNO}_{3}$ & 2.84 & 1.08 \\
\hline $\mathrm{NaNO}_{2}$ & 0.370 & 0.740 \\
\hline $\mathrm{NaAlO}_{2}$ & 0.320 & 0.270 \\
\hline $\mathrm{Na}_{2} \mathrm{SO}_{4}$ & 0.220 & 0.0300 \\
\hline $\mathrm{Na}_{2} \mathrm{CO}_{3}$ & 0.160 & 0.170 \\
\hline $\mathrm{NaCl}$ & 0.0400 & 0.0100 \\
\hline $\mathrm{NaF}$ & 0.0500 & 0.0100 \\
\hline $\mathrm{Na}_{2} \mathrm{HPO}_{4}$ & 0.0100 & 0.0080 \\
\hline $\mathrm{Na}_{2} \mathrm{C}_{2} \mathrm{O}_{4}$ & 0.00800 & 0.0080 \\
\hline $\mathrm{Na}_{2} \mathrm{SiO}_{3}$ & 0.00400 & 0.00400 \\
\hline $\mathrm{Na}_{2} \mathrm{MoO}_{4}$ & 0.0002 & 0.0002 \\
\hline $\mathrm{KNO}_{3}$ & 0.00410 & 0.0300 \\
\hline $\mathrm{CsCl}$ & 0.00014 & 0.00037 \\
\hline
\end{tabular}


We chose these two salt solutions based on customer recommendations of the two likely end conditions of Tank $50 \mathrm{H}$ after addition of high sodium tank supernates: high hydroxide and high nitrate. Technicians added enough $\mathrm{Fe}\left(\mathrm{NO}_{3}\right)_{3} \cdot 9 \mathrm{H}_{2} \mathrm{O}$ to achieve an iron concentration of $500 \mathrm{ppm}$. They performed $\mathrm{pH}$ adjustment with a slow, controlled addition of $70 \mathrm{wt} \%$ nitric acid and confirmed by both a $\mathrm{pH}$ meter and colorimetric $\mathrm{pH}$ paper. We added enough hydrogen peroxide to provide 3 moles of $\mathrm{H}_{2} \mathrm{O}_{2}$ per moles of carbon (i.e., $5.76 \mathrm{~mL}$ of $50 \mathrm{wt} \%$ ). Table 2 lists the matrix for all of the KTPB experiments. An examination of the table shows that the majority of the experiments

Table 2. Matrix for TPB Experiments ${ }^{\partial}$

\begin{tabular}{|l|c|c|c|c|c|c|c|c|}
\hline Supernate & $\mathrm{pH}$ & $\begin{array}{c}\text { Start } \\
\mathrm{TPB} \\
(\mathrm{mg} / \mathrm{L})\end{array}$ & $\begin{array}{c}\text { End } \\
\text { TPB } \\
(\mathrm{mg} / \mathrm{L})\end{array}$ & $\begin{array}{c}\text { End } \\
3 \mathrm{~PB} \\
(\mathrm{mg} / \mathrm{L})\end{array}$ & $\begin{array}{c}\text { End } \\
2 \mathrm{~PB} \\
(\mathrm{mg} / \mathrm{L})\end{array}$ & $\begin{array}{c}\text { End } \\
1 \mathrm{~PB} \\
(\mathrm{mg} / \mathrm{L})\end{array}$ & $\begin{array}{c}\text { End } \\
\text { Phenol } \\
(\mathrm{mg} / \mathrm{L})\end{array}$ & $\begin{array}{c}\% \\
\mathrm{TPB} \\
\text { Destr. }\end{array}$ \\
\hline High $\mathrm{OH}$ & 14 & 4180 & 3392 & 73 & 184 & 39 & 7 & 18.8 \\
\hline High $\mathrm{OH}$ & 13 & 4721 & 4481 & $<100$ & $<100$ & $<100$ & $<100$ & 5.1 \\
\hline Low OH & 13 & 4721 & 4565 & $<100$ & $<100$ & $<100$ & $<100$ & 3.3 \\
\hline Low OH & 11.5 & 4731 & 4345 & $<100$ & $<100$ & $<100$ & $<100$ & 8.2 \\
\hline Low OH & 11.5 & 4731 & 4701 & $<100$ & $<100$ & $<100$ & $<100$ & 0.7 \\
\hline Low OH & 10 & 4721 & 4806 & $<100$ & $<100$ & $<100$ & $<100$ & 0 \\
\hline Low OH & 9 & 4682 & 3951 & $<100$ & $<100$ & $<100$ & 732 & 15.6 \\
\hline
\end{tabular}

$1 \sigma$ analytical uncertainty for HPLC is $10 \%$ for sample results $>15 \mathrm{ppm}$ and $20 \%$ for results $\leq 15 \mathrm{ppm}$

showed essentially no reaction. While the experiment ( $1^{\text {st }}$ in the table) with High $\mathrm{OH}$ and $\mathrm{pH}$ of 14 indicated 19\% destruction of TPB, we believe that this result is false because we see detectable hydrolysis products $(3,2,1 \mathrm{~PB})$ and little phenol (which is probably a common oxidation product of TPB). It is possible this result indicates that hydrolysis occurred during the analytical preparation (part of the analysis is a $\mathrm{pH}$ adjustment). On the other hand, the last experiment in the table (Low OH, $\mathrm{pH} 9$ ) does seem to show a real reaction. An apparent meaningful decrease in TPB is matched by an almost equal increase in phenol concentration. From this data, it would appear that $\mathrm{pH}$ values $<10$ are required for a noticeable Fenton's reaction to occur within four hours.

\subsubsection{Tests with Phenol}

While KTPB is a better surrogate for actual Tank $50 \mathrm{H}$ solids, the insolubility of the KTPB adds mass transfer as a variable to the Fenton's reaction. The reactivity of an insoluble material can be masked by its inability to contribute to a homogenous reaction. To try and avoid this issue, we decided to try several experiments with a soluble organic

\footnotetext{
${ }^{\partial}$ Historically, TPB analysis is returned to us in terms of NaTPB. We have corrected results in Table 2 to reflect KTPB.
} 
material that at least had some similarity to KTPB; phenol (Figure 3). Phenol has an aromatic character like TPB, but has appreciably greater solubility in caustic solutions. In each of the phenol reactions, our target amount of phenol equaled $524 \mathrm{mg}$. We added enough $\mathrm{Fe}\left(\mathrm{NO}_{3}\right)_{3} \cdot 9 \mathrm{H}_{2} \mathrm{O}$ to achieve an iron concentration of $500 \mathrm{ppm}$. We used the same two salt solutions (100 mL volume) used in the KTPB tests (see section 4.1.1, above), although the $\mathrm{pH}$ remained at 14 for all three tests. We performed each reaction at room temperature. Technicians added enough hydrogen peroxide to provide 3 moles of $\mathrm{H}_{2} \mathrm{O}_{2}$ per moles of carbon (i.e., $5.76 \mathrm{~mL}$ of $50 \mathrm{wt} \%$ ). Table 3 lists the matrix for all of the phenol experiments.

Figure 3. Structures of TPB and Phenol

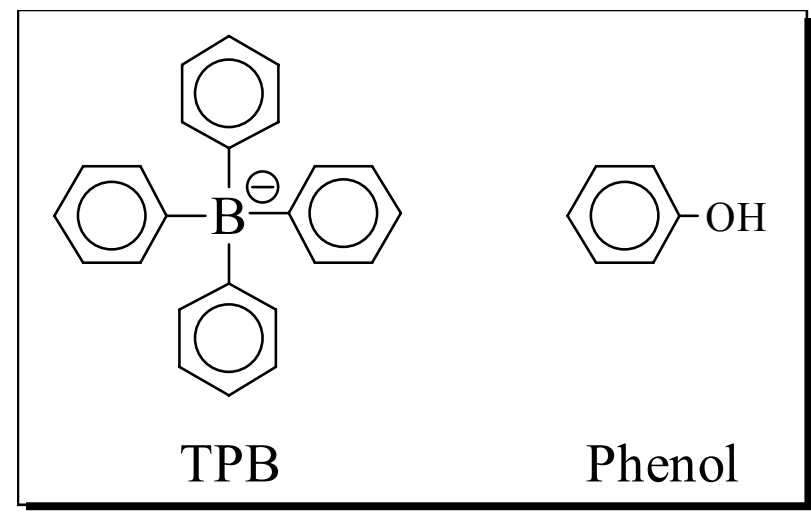

Table 3. Matrix for Phenol Experiments

\begin{tabular}{|l|c|c|c|c|}
\hline Supernate & $\mathrm{pH}$ & $\begin{array}{c}\text { Start } \\
\text { Phenol } \\
(\mathrm{mg} / \mathrm{L})\end{array}$ & $\begin{array}{c}\text { End } \\
\text { Phenol } \\
(\mathrm{mg} / \mathrm{L})\end{array}$ & $\begin{array}{c}\% \\
\text { Phenol } \\
\text { Destr. }\end{array}$ \\
\hline High $\mathrm{OH}$ & 14 & 4375 & 4090 & 6.5 \\
\hline Low $\mathrm{OH}$ & 14 & 4375 & 4070 & 7.0 \\
\hline Low $\mathrm{OH}$ & 14 & 4383 & 4390 & 0 \\
\hline
\end{tabular}

$1 \sigma$ analytical uncertainty for HPLC is $10 \%$ for sample results $>15 \mathrm{ppm}$ and $20 \%$ for results $\leq 15 \mathrm{ppm}$

The results of the three tests show essentially no destruction of the phenol (analysis by HPLC) since we place the analytical variance at $\sim 10 \%$. As phenol is readily oxidized and is soluble, the lack of any reaction leads us to believe that at $\mathrm{pH} 14$, no Fenton's reaction can occur.

\subsubsection{Tests with Actual Tank 50H Material}

Finally, we performed two Fenton's Reagent tests with actual Tank $50 \mathrm{H}$ material. While we had planned to first firmly establish a set of optimal Fenton's reaction conditions, a customer request accelerated the tests with actual waste. In these two tests, we used 100 
$\mathrm{mL}$ of well-mixed Tank $50 \mathrm{H}$ slurry. Technicians added enough $\mathrm{Fe}\left(\mathrm{NO}_{3}\right)_{3} \cdot 9 \mathrm{H}_{2} \mathrm{O}$ to achieve an iron concentration of $500 \mathrm{ppm}$ and adjusted the $\mathrm{pH}$ with a slow, controlled addition of $70 \mathrm{wt} \%$ nitric acid as confirmed by colorimetric $\mathrm{pH}$ paper. (We did not have a pH meter available for use in the radioactive hood.) We added the same amount of hydrogen peroxide as in the previous tests (i.e., $5.76 \mathrm{~mL}$ of $50 \mathrm{wt} \%$ ), and ran each reaction at room temperature. The two experiments differed only in the addition of the ECC group of catalysts (see Table 5) to one of the experiments. Table 6 lists the matrix for all of the KTPB experiments.

Table 5. Enhanced Catalyst Composition (ECC) Set

\begin{tabular}{|c|c|c|}
\hline Component & Compound & $\begin{array}{c}\text { Species } \\
\text { Concentration } \\
\text { in Slurry } \\
(\mathrm{mg} / \mathrm{L})\end{array}$ \\
\hline $\mathrm{Pd}$ & $\mathrm{Pd}\left(\mathrm{NO}_{3}\right)_{2}$ & \begin{tabular}{|c|}
13.0 \\
\end{tabular} \\
\hline $\mathrm{Cu}$ & $\mathrm{Cu}\left(\mathrm{SO}_{4}\right) \bullet 5 \mathrm{H}_{2} \mathrm{O}$ & 3.7 \\
\hline $\mathrm{Hg}$ & $\mathrm{Hg}\left(\mathrm{NO}_{3}\right)_{2} \bullet \mathrm{H}_{2} \mathrm{O}$ & 2.2 \\
\hline diphenylmercury & $\left(\mathrm{C}_{6} \mathrm{H}_{5}\right)_{2} \mathrm{Hg}$ & 150 \\
\hline $\mathrm{Mo} / \mathrm{Cr} / \mathrm{Si} / \mathrm{Se} / \mathrm{As}$ & $\begin{array}{c}\mathrm{Na}_{2} \mathrm{MoO}_{4} \bullet 2 \mathrm{H}_{2} \mathrm{O} \\
\mathrm{Na}_{2} \mathrm{CrO}_{4} \\
\mathrm{Na}_{2} \mathrm{SiO}_{3} \bullet 9 \mathrm{H}_{2} \mathrm{O} \\
\mathrm{Na}_{2} \mathrm{SeO}_{4} \\
\mathrm{As}_{2} \mathrm{O}_{3}\end{array}$ & $\begin{array}{c}12 \\
60 \\
16 \\
1 \\
0.04\end{array}$ \\
\hline $\mathrm{Zn} / \mathrm{Pb} / \mathrm{Fe}$ & $\begin{array}{c}\mathrm{Zn}\left(\mathrm{NO}_{3}\right)_{2} \bullet 4 \mathrm{H}_{2} \mathrm{O} \\
\mathrm{Pb}\left(\mathrm{NO}_{3}\right)_{2} \\
\mathrm{Fe}\left(\mathrm{NO}_{3}\right)_{3} \bullet 9 \mathrm{H}_{2} \mathrm{O}\end{array}$ & $\begin{array}{l}8.8 \\
1.2 \\
2.6 \\
\end{array}$ \\
\hline $\mathrm{Sn}$ & $\mathrm{SnCl}_{2}$ & 2.1 \\
\hline $\mathrm{Ca} / \mathrm{La} / \mathrm{Co}$ & $\begin{array}{l}\mathrm{Ca}\left(\mathrm{NO}_{3}\right)_{2} \bullet 4 \mathrm{H}_{2} \mathrm{O} \\
\mathrm{La}\left(\mathrm{NO}_{3}\right)_{3} \bullet 6 \mathrm{H}_{2} \mathrm{O} \\
\mathrm{Co}\left(\mathrm{NO}_{3}\right)_{2} \bullet 6 \mathrm{H}_{2} \mathrm{O}\end{array}$ & $\begin{array}{l}12.2 \\
0.05 \\
0.04\end{array}$ \\
\hline $\mathrm{Cd} / \mathrm{Ce}$ & $\begin{array}{l}\mathrm{Cd}\left(\mathrm{NO}_{3}\right)_{2} \bullet 4 \mathrm{H}_{2} \mathrm{O} \\
\mathrm{Ce}\left(\mathrm{NO}_{3}\right)_{3} \bullet 6 \mathrm{H}_{2} \mathrm{O}\end{array}$ & $\begin{array}{l}0.4 \\
0.3 \\
\end{array}$ \\
\hline $\mathrm{Rh}$ & $\mathrm{Rh}\left(\mathrm{NO}_{3}\right)_{3}$ & 1.4 \\
\hline $\mathrm{Ag}$ & $\mathrm{AgNO}_{3}$ & 6.8 \\
\hline $\mathrm{Ru}$ & $\mathrm{RuCl}_{3} \bullet \times \mathrm{H}_{2} \mathrm{O}$ & 5.4 \\
\hline sludge & Sludge & 500 \\
\hline MST & MST & 500 \\
\hline
\end{tabular}

Table 6. Matrix for Actual Tank 50H Experiments

\begin{tabular}{|l|c|c|c|c|c|c|c|c|c|}
\hline Supernate & $\mathrm{pH}$ & $\begin{array}{c}\text { ECC } \\
\text { Added } \\
?\end{array}$ & $\begin{array}{c}\text { Start } \\
\text { TPB } \\
(\mathrm{mg} / \mathrm{L})\end{array}$ & $\begin{array}{c}\text { End } \\
\text { TPB } \\
(\mathrm{mg} / \mathrm{L})\end{array}$ & $\begin{array}{c}\text { End } \\
3 \mathrm{~PB} \\
(\mathrm{mg} / \mathrm{L})\end{array}$ & $\begin{array}{c}\text { End } \\
2 \mathrm{~PB} \\
(\mathrm{mg} / \mathrm{L})\end{array}$ & $\begin{array}{c}\text { End } \\
1 \mathrm{~PB} \\
(\mathrm{mg} / \mathrm{L})\end{array}$ & $\begin{array}{c}\text { End } \\
\text { Phenol } \\
(\mathrm{mg} / \mathrm{L})\end{array}$ & $\begin{array}{c}\% \\
\text { TPB } \\
\text { Destr. }\end{array}$ \\
\hline High OH & 9.5 & NO & 454 & 443 & $<20$ & $<20$ & $<20$ & 20 & 2.5 \\
\hline High OH & 9.5 & YES & 454 & 378 & $<20$ & $<20$ & $<20$ & 53 & 16.8 \\
\hline
\end{tabular}

$1 \sigma$ analytical uncertainty for HPLC is $10 \%$ for sample results $>15 \mathrm{ppm}$ and $20 \%$ for results $\leq 15 \mathrm{ppm}$ 
WSRC-TR-2003-00234

The results suggest the presence of the ECC group had an appreciable effect on the reaction. With no ECC present, no effective reaction occurred. With ECC present, a $17 \%$ destruction occurred over the 4 hour time period.

When considering all the experiments, our data seems to indicate that the $\mathrm{pH}$ of the solution is the primary controlling factor. $\mathrm{pH}$ values $<10.0$ are required for a Fenton's reaction to occur. A second factor is the presence of the ECC materials. Their presence appears to increase or facilitate the destruction of TPB (although we cannot discern if this is from hydrolysis or from the Fenton's reaction).

\subsection{Results of Hydrolysis Tests at $\mathrm{pH} 14$}

We performed a series of four hydrolysis tests, each using $30 \mathrm{~mL}$ of well-mixed actual Tank $50 \mathrm{H}$ slurry ( $\mathrm{pH} 14$ ). Each experiment used five bottles under identical conditions. The only difference in any series of 5 bottles involved the time of analysis $(1,2,3,14$, and 33 days after the start of each test) via HPLC. The starting concentration of TPB measured $\sim 450 \mathrm{ppm}$.

The first test involved hydrolysis at room temperature with $100 \mathrm{ppm}$ of copper (added in the form of $\left.\mathrm{Cu}\left(\mathrm{NO}_{3}\right)_{2} \cdot 2.5 \mathrm{H}_{2} \mathrm{O}\right)$. Table 7 lists the HPLC results from this test.

Table 7. HPLC Results From Room Temperature, 100 ppm Copper Test

\begin{tabular}{|c|c|c|c|c|c|}
\hline Species & Day 1 & Day 2 & Day 3 & Day 14 & Day 33 \\
\hline TPB & 471 & 464 & 493 & 501 & 452 \\
\hline 3PB & $<5.0$ & $<5.0$ & $<5.0$ & $<5.0$ & $<10$ \\
\hline 2PB & $<5.0$ & $<5.0$ & $<5.0$ & $<5.0$ & $<10$ \\
\hline 1PB & $<5.0$ & $<5.0$ & $<5.0$ & $<5.0$ & $<10$ \\
\hline Phenol & 31 & 29 & 30 & 29 & 28 \\
\hline
\end{tabular}

$1 \sigma$ analytical uncertainty for HPLC is $10 \%$ for sample results $>15 \mathrm{ppm}$ and $20 \%$ for results $\leq 15 \mathrm{ppm}$

From these results, we conclude that there is no effective destruction of the TPB. Not only does the TPB concentration show no downward trend, but there is no indication of hydrolysis products $(3,2,1 \mathrm{~PB})$ being formed.

The next test occurred at room temperature with no added copper (Table 8) and served as a measure of the base stability of the Tank $50 \mathrm{H}$ material. 
WSRC-TR-2003-00234

Table 8. HPLC Results From Room Temperature, No Copper Test

\begin{tabular}{|c|c|c|c|c|c|}
\hline Species & Day 1 & Day 2 & Day 3 & Day 14 & Day 33 \\
\hline TPB & 487 & 492 & 479 & 458 & 468 \\
\hline 3PB & $<5.0$ & $<5.0$ & $<5.0$ & $<5.0$ & $<10$ \\
\hline 2PB & $<5.0$ & $<5.0$ & $<5.0$ & $<5.0$ & $<10$ \\
\hline 1PB & $<5.0$ & $<5.0$ & $<5.0$ & $<5.0$ & $<10$ \\
\hline Phenol & 32 & 30 & 30 & 29 & 28 \\
\hline
\end{tabular}

$1 \sigma$ analytical uncertainty for HPLC is $10 \%$ for sample results $>15 \mathrm{ppm}$ and $20 \%$ for results $\leq 15 \mathrm{ppm}$

As the analogous test with added copper shows no reaction, it is not surprising that this reaction also shows no sign of hydrolysis. There is no downward trend in TPB and no hydrolysis products formed.

The third test occurred at $50{ }^{\circ} \mathrm{C}$ with $100 \mathrm{ppm}$ of added copper (Table 9). Of all the tests, this one had the best potential to show hydrolysis.

Table 9. HPLC Results From $50{ }^{\circ} \mathrm{C}, 100$ ppm Copper Test

\begin{tabular}{|c|c|c|c|c|c|}
\hline Species & Day 1 & Day 2 & Day 3 & Day 14 & Day 33 \\
\hline TPB & 469 & 487 & 481 & 469 & 410 \\
\hline 3PB & $<5.0$ & $<5.0$ & $<5.0$ & $<5.0$ & $<10$ \\
\hline 2PB & $<5.0$ & $<5.0$ & $<5.0$ & $<5.0$ & $<10$ \\
\hline 1PB & $<5.0$ & $<5.0$ & $<5.0$ & $<5.0$ & $<10$ \\
\hline Phenol & 32 & 34 & 36 & 40 & 51 \\
\hline
\end{tabular}

$1 \sigma$ analytical uncertainty for HPLC is $10 \%$ for sample results $>15 \mathrm{ppm}$ and $20 \%$ for results $\leq 15 \mathrm{ppm}$

Unfortunately, this test also showed minimal indication of TPB decomposition. Approximately $14 \%$ of the TPB decomposed over the thirty three day period.

The final test occurred at $50{ }^{\circ} \mathrm{C}$ temperature, with no added copper (Table 10).

Table 10. HPLC Results From $50{ }^{\circ} \mathrm{C}$, no Copper Test

\begin{tabular}{|c|c|c|c|c|c|}
\hline Species & Day 1 & Day 2 & Day 3 & Day 14 & Day 33 \\
\hline TPB & 442 & 489 & 482 & 492 & 434 \\
\hline 3PB & $<5.0$ & $<5.0$ & $<5.0$ & $<5.0$ & $<10$ \\
\hline 2PB & $<5.0$ & $<5.0$ & $<5.0$ & $<5.0$ & $<10$ \\
\hline 1PB & $<5.0$ & $<5.0$ & $<5.0$ & $<5.0$ & $<10$ \\
\hline Phenol & 32 & 33 & 33 & 34 & 44 \\
\hline
\end{tabular}

$1 \sigma$ analytical uncertainty for HPLC is $10 \%$ for sample results $>15 \mathrm{ppm}$ and $20 \%$ for results $\leq 15 \mathrm{ppm}$ 
WSRC-TR-2003-00234

This last test also shows no indication of significant TPB decomposition.

\subsection{Conclusions}

We performed a series of scoping tests to examine reactivity - to hydrolysis, catalysis, and Fenton's reagent - of Tank $50 \mathrm{H}$ waste. These experiments provide the following conclusions.

- Using Fenton's Reagent and KTPB or phenol as the Tank 50H surrogate, no reaction occurred at $\mathrm{pH}$ ranges greater than 9.

- Using Fenton's Reagent and actual Tank 50H slurry, a reaction occurred at a $\mathrm{pH}$ of 9.5 in the presence of ECC additives. The ECC additives may help promote a reaction at higher $\mathrm{pH}$ values than normally available in a Fenton's reaction. As the current set of results cannot differentiate whether the ECC additives are causing hydrolysis or aiding the Fenton's reaction, we plan on performing a control experiment. This document will be revised when that data becomes available.

- After a thirty three day period, the hydrolysis reactions were too slow to be viable. Longer times may be required in order for significant organic destruction via hydrolysis reactions at high $\mathrm{pH}$. 
WSRC-TR-2003-00234

\subsection{References}

1 C. D. Banaszewski, "Engineering Path Forward HTF-PF-2002-0014: Tank 50 Solids", HLW-STE-2002-00388, October 23, 2002.

2 W. R. Wilmarth, "Results of Sample Analysis from Solids Removed from Tank 50H", WSRC-TR-2002-00506, November 1, 2002.

3 C. D. Banaszewski, "Tank 50 Solids Mound Volume Calculation", J-CLC-H-00793, Rev. 0, November 2002.

${ }^{4}$ D. P. Lambert and J. T. Mills, "Tank 50H Flammability Calculations", WSRC-TR2003-00124, Rev. 1, March 20, 2003.

${ }^{5}$ R. A. Adams, et al., "HLW Tank 48H Disposition Alternatives Identification -- Phase I and II Summary Report”, WSRC-RP-2002-00154, Rev. 1, July 15, 2002.

${ }^{6}$ Reference Library Peroxide Applications, http://www.h2o2.com/applications/industrialwastewater/fentonsReagent.html, January 29, 2003.

${ }^{7}$ K. M. Jerome, B. Riha, and B. B. Looney, "Final Report for Demonstration of In Situ Oxidation of DNAPL Using the Geo-Cleanse ${ }^{\circledR}$ Technology”, WSRC-TR-97-00283, 1997.

${ }^{8}$ K. B. Martin, T. B. Peters, T. L. White, "Decomposition Reaction Rates for Phenylborate Species Contained in Tank 49H Waste", WSRC-TR-2000-00151, Rev. 1, June 20, 2000. 